\title{
Synovial membrane asks for independence
}

\author{
S. Moskalewski, A. Osiecka-Iwan, E. Jankowska-Steifer, A. Hyc \\ Department of Histology and Embryology, Warsaw Medical University, Warsaw, Poland
}

[Received 12 May 2014; Accepted 22 May 2014]

\begin{abstract}
Synovial membrane is traditionally considered as a part of the joint capsule. It, however, differs from fibrous part of the capsule in development, structure, function, vascularisation, innervation and involvement in pathological processes. Moreover, in some areas, it even does not contact with the fibrous capsule. Thus, it appears that the synovial membrane should be considered as an independent organ and not as the lining of the joint capsule. (Folia Morphol 2014; 73, 4: 395-398)
\end{abstract}

Key words: synovial membrane, joint capsule, anatomical terminology

\section{INTRODUCTION}

After getting familiar with the synovial membrane in the course of various investigations $[17,18]$ we feel justified to present its case. In this short review we compare several features of synovial membrane and fibrous part of the joint capsule and conclude that the differences are so striking that the synovial membrane should be considered as independent organ.

History and definition. The history of studies on the synovial membrane began at the end of the seventeenth century and is presented in several papers describing how the synovial membrane was seen by early investigators and how its modern concept developed [2, 8, 11, 19, 20, 36]. According to Sigurdson [36], the name "synovial membrane" was applied in 1763 by Bonn to the inner lining of joint cavities, while before this structure was included in the "capsular ligaments" of the joints.

Key [20] defines the synovial membrane of a diartrodial joint as loose, flexible tube which is attached around the margins of the articular cartilages, covering the ends of the bones which form the joint. The articular capsule consists of a fibrous or ligamentous layer which is lined by stratum synoviale (synonymous with synovial membrane or synovium). These 2 layers are often so intimately fused that it is not possible to identify a distinct boundary between them.
Ghadially [13] called the lining layer adjacent to the joint space the "synovial intima" and the supportive or backing layer the "subsynovial tissue" or "subintimal tissue". On its external surface the subintimal tissue merges with the fibrous capsule of the joint.

The synovial membrane lines the fibrous capsule and intraarticular ligaments and tendons, and is reflected on to the intracapsular bone. In the latter situation it is unrelated to the fibrous capsule and cannot be regarded as part of it $[2,20]$. Terminologia Anatomica [40], says that the joint capsule is composed of fibrous membrane (synonym: fibrous layer) and synovial membrane (synonym: synovial layer), and these terms are often used in anatomy textbooks.

\section{STRUCTURE}

The synovial membrane is lined by 2 types of synoviocytes: macrophage-like type $A$ cells and fibroblast-like B cells [4, 28, 32, 42] usually resting on the areolar tissue. Contrary to that, fibrous part of the joint capsule has no specific lining and is build up by well-organised, parallel arrangement of collagen fibres with intervening fibroblasts [6]. All parts of the capsule contain types I, III and VI collagens as well as dermatan and keratan sulphate [23, 25]. 


\section{DEVELOPMENT}

Formation of synovial membrane and fibrous joint capsule is strictly connected with joint formation. Joints in long bones form through the development of a noncartilaginous region known as the interzone [1]. The first over sign of joint formation is the appearance of interzone at each future joint site. Pacifici et al. [30, 31] found that perijoint mesenchymal cells expressing Gdf5, located immediately adjacent to incipient joints, migrate into the interzone, constitute a distinct cohort of progenitor cells and are eventually found in epiphyseal articular layer and joint capsule. The authors, however, did not specify whether they mean only synovium or also fibrous part of the joint capsule. In the further work Koyama et al. [22] reported that the Gdf5-expressing cells give rise to most if not all joint tissues including articular cartilage, ligaments and inner synovial lining. Origin of fibrous joint capsule was not described by these authors, but the assumption that it was formed by the perijoint mesenchymal tissue remaining after migration of Gdf5 expressing cells into interzone seems justified.

\section{INNERVATION}

Normal synovium [24] as well as pathological synovial tissue contain nociceptive sensory innervation producing pro- and anti-inflammatory neuropeptides $[10,29,39]$. In the stratum fibrosum of the joint capsule and the adjacent connective tissue sensory nerve endings serving as mechanoreceptors (lamellated corpuscles of the Pacini type, Ruffini corpuscles and Golgi-tendon organs) predominate $[3,12,21,43]$.

\section{VASCULARISATION}

According to Davies and Edwards [8], the first description of the blood vascular pattern in the synovial membrane is that of William Hunter [16] who stated: "All round the neck of the bone there is a greater number of arteries and veins which ramify into smaller branches and communicate with one another by frequent anastomoses like those of the mesentery. This might be called the circulus articuli vasculosus, the vascular border of the joint." In studies on synovial membrane injected with India ink or barium sulphate suspension Davies and Edwards [8] found that in the looser and more areolar areas larger vessels, both arteries and veins, run in the deeper part of the membrane, close to the capsular tissues and parallel to the synovial surface. They branch infrequently in tree-like fashion and anastomose at irregular intervals to form wide meshed plexuses of arteries and veins. These plexuses intercommunicate freely, whilst the innermost supplies a rich capillary bed to the surface of the synovial membrane.

In the ligaments and capsules composed of very compact fibrous tissue, the larger vessels, arterioles and venules, usually arranged in groups of 3 or more, course longitudinally between the fascicles and fibrous tissue bundles and are fed from vessels located outside the joint. The longitudinal vessels communicate frequently through smaller vessels running transversely and around the connective tissue bundles.

\section{THE SYNOVIAL MICROCIRCULATION}

Synovial membrane contains a dense, superficial capillary network situated just below the surface of the synovial membrane in the narrow space between the synovial lining and the underlying fat cells. The structure of these superficial capillaries was strikingly polarised; the portion of their wall farthest from the synovial lining usually contains nuclei; the closest is extremely attenuated and contains numerous fenestrae closed by the diaphragm. Deeper synovial venules and capillaries do not have fenestrations [13, $34,37,38,41]$. The synovial membrane in conjunction with the microvascularity is known as the synovial-vascularity barrier [5]. The capillaries of the fibrous part of joint capsule are few and of the continuous variety $[13,38]$.

\section{LYMPHATIC VESSELS}

According to Davies [7] in the most parts of the synovial membrane the large lymphatics are arranged in the form of a wide-meshed, freely anastomosing, polygonal pattern within which are numerous, blind ending, smaller tributaries, frequently showing terminal lacuniform enlargements. Over the more fibrous areas of the synovial membrane, and towards the cartilaginous articular margins, the plexus becomes attenuated; its vessels become finer and fewer, and their anastomoses become less frequent. Unlike the blood capillaries, these fine lymph vessels terminate blind at some distance from the articular margin.

\section{PATHOLOGY}

Synovial hyperplasia is characteristic feature of rheumatoid arthritis $[27,35]$ and synovial membrane may be even recognised as the primary pathogenetic site in this disease [15]. 
Synovial inflammation is also a significant feature of osteoarthritis $[9,33]$. The main clinical problem involving the fibrous part of the joint capsule is posttraumatic stiffness. The affected joint capsule is characterised by irreversible biomechanical and biochemical fibrogenic changes strikingly similar to those observed in many other fibroproliferative human conditions $[14,26]$.

\section{DECLARATION OF INDEPENDENCE}

Already in 1961 Barnett et al. [2] observed that physiologically there is little to commend the idea that the synovial membrane and fibrous capsule are two parts of the same structure. Their opinion, however, was not reflected in change of terminology. With the passing years more and more evidence accumulated indicating basic differences between these two structures. Synovial membrane differs in all particulars from the fibrous parts of the joint capsule. Moreover, in some areas it even does not adhere to it. Thus, it would be time to release it from the subservient position of the fibrous capsule lining. Why not say that joint capsule is formed by the collagenous or fibrous tissue and synovial membrane constitutes an independent organ, differing from the fibrous part of the joint capsule in development, structure, function, vascularisation and innervation. The significance of synovial membrane is particularly striking in its pathological states, and it would be more up to the point to say that rheumatoid arthritis or osteoarthritis are diseases with involvement of synovial membrane as an independent organ and not as a part of joint capsule.

\section{ACKNOWLEDGEMENTS}

Publication was funded by the National Science Centre (Poland) on the basis of decision number: DEC-2012/05/B/NZ4/02646

\section{REFERENCES}

1. Archer CW, Dowthwaite GP, Francis-West P (2003) Development of synovial joints. Birth Defects Res (Part C), 69: 144-155.

2. Barnett CH, Davies DV, MacConnaill MA (1961) Synovial joints. Their structure and mechanics. Longman, Green \& Co., Ltd, London.

3. Backenköhler U, Halata Z, Strasmann TJ (1996) The sensory innervation of the shoulder joint of the mouse. Ann Anat, 178: 173-181.

4. Barland P, Novikoff AB, Hamerman D (1962) Electron microscopy of the human synovial membrane. J Cell Biol, 14: 207-215.
5. Berumen-Nafarrate E, Leal-Berumen, Luevano E, Solis FJ, Muñoz-Esteves E (2002) Synovial tissue and synovial fluid. J Knee Surg, 15: 46-48.

6. Cohen MS, Schimmel DR, Masuda K, Hastings H 2nd, Muehleman C (2007) Structural and biochemical evaluation of the elbow capsule after trauma. J Shoulder Elbow Surg, 16: 484-490.

7. Davies DV (1946) The lymphatics of the synovial membrane. J Anat, 80: 21-23.

8. Davies DV, Edwards DAW (1948) The blood supply of the synovial membrane and intra-articular structures. Ann R Coll Surg Engl, 2: 142-156.

9. de Lange-Brokaar BJ, loan-Facsinay A, van Osch GJ, Zuurmond AM, Schoones J, Toes RE, Huizinga TW, Kloppenburg M (2012) Synovial inflammation, immune cells and their cytokines in osteoarthritis: a review. Osteoarthritis Cartilage, 20: 1484-1499.

10. Dirmeier M, Capellino S, Schubert T, Angele P, Anders S, Straub RH (2008) Lower density of synovial nerve fibres positive for calcitonin gene-related peptide relative to substance $P$ in rheumatoid arthritis but not in osteoarthritis. Rheumatology, 47: 36-40.

11. Franceschini DP (1930) Ricerche istologiche sulle articolazioni. Arch Ital Anat Embriol, 27: 76-179.

12. Freeman MAR, Wyke $B$ (1967) The innervation of the knee joint. An anatomical and histological study in the cat. J Anat, 101: 505-532.

13. Ghadially FN (1983) Fine structure of synovial joints. Butterworths, London.

14. Hildebrand KA, Zhang M, Germscheid NM, Wang C, Hart DA (2008) Cellular, matrix, and growth factor components of the joint capsuleare modified early in the process of posttraumatic contracture formation in a rabbit model. Acta Orthop, 79: 116-125.

15. Humby F, Manzo A, Kirkham B, Pitzalis C (2007) The synovial membrane as a prognostic tool in rheumatoid arthritis. Autoimmun Rev, 6: 248-252.

16. Hunter W (1995) On the structure and diseases of articulating cartilages. 1743. Clin Orthop Relat Res, 317: 3-6.

17. Hyc A, Osiecka-Iwan A, Niderla-Bielinska J, Jankowska-Steifer E, Moskalewski S (2009) Pro- and anti-inflammatory cytokines increase hyaluronan production by rat synovial membrane in vitro. Int J Mol Med, 24: 579-585.

18. Hyc A, Osiecka-Iwan A, Niderla-Bielinska J, Moskalewski S (2011) Influence of LPS, TNF, TGF-beta1 and IL-4 on the expression of MMPs, TIMPs and selected cytokines in rat synovial membranes incubated in vitro. Int J Mol Med, 27: 127-137.

19. Johansson HE, Rejnö S (1976) Light and electron microscopic investigation of equine synovial membrane. Acta Vet Scand, 17: 153-168.

20. Key JA (1928) The synovial membrane of joints and bursae. In: Cowdry EV ed. Special cytology. PB Hoeber, New York, pp. 735-766.

21. Kottinen YT, Tiainen MV, Gomez-Barrena E, Hukkanen M, Salo J (2006) Innervation of the joint and role of neuropeptides. Ann NY Acad Sci, 1069: 149-154.

22. Koyama E, Shibukawa $Y$, Nagayama M, Sugito $H$, Young B, Yuasa T, Okabe T, Ochiai T, Kamiya N, Rountree RB, KingsleyDM, Iwamoto M, Enomoto-Iwamoto M, Pacifici M (2008) A distinct cohort of progenitor cells participates in synovial 
joint and articular cartilage formation during mouse limb skeletogenesis. Dev Biol, 316: 62-73.

23. Lewis AR, Ralphs JR, Kneafsey B, Benjamin M (1998) Distribution of collagens and glycosaminoglycans in the joint capsule of the proximal interphalangeal joint of the human finger. Anat Rec, 250: 281-291.

24. Mapp PI, Kidd BL, Gibson SJ, Terry JM, Revell PA, Ibrahim NBN, Blake DR, Polak JM (1990) Substance P-, calcitonin gene-related peptide and C-flanking peptide of neuropeptide Y-immunoreactive fibres are present in normal synovium but depleted in patients with rheumatoid arthritis. Neuroscience, 37: 143-153.

25. Matsumoto F, Trudel G, Uhthoff HK (2002) High collagen type I and low collagen type III levels in knee joint contracture: an immunohistochemical study with histological correlate. Acta Orthop Scand, 73: 335-343.

26. Monument MJ, Hart DA. Salo PT, Befus AD, Hildebrand KA (2013) Posttraumatic elbow contractures: targeting neuroinflammatory fibrogenic mechanisms. J Orthop Sci, 18: 869-877.

27. Neumann E, Lefèvre $S$, Zimmermann B, Gay $S$, Müller-Ladner U (2010) Rheumatoid arthritis progression mediated by activated synovial fibroblasts. Trends Mol Med, 16: 458-468.

28. Nozawa-Inoue K, Amizuka N, Ikeda N, Suzuki A, Kawano Y, Maeda T (2003) Synovial membrane in the temporomandibular joint - its morphology, function and development. Arch Histol Cytol, 66: 289-306.

29. Ossyssek B, Anders S, Grifka J, Straub RH (2011) Surgical synovectomy decreases density of sensory nerve fibers in synovial tissue of non-inflamed controls and rheumatoid arthritis patients. J Orthop Res, 29: 297-302.

30. Pacifici M, Koyama E, Iwamoto M (2005) Mechanisms of synovial joint and articular cartilage formation: recent advances, but many lingering mysteries. Birth Defects Res (Part C), 75: 237-248.

31. Pacifici M, Koyama E, Shibukawa $Y$, Wu C, Tamamura $Y$, Enomoto-Iwamoto M, Iwamoto M (2006) Cellular and molecular mechanisms of synovial joint and articular cartilage formation. Ann NY Acad Sci, 1068: 74-86.

32. Revell PA, al-Saffar N, Fish S, Osei D (1995) Extracellular matrix of the synovial intimal cell layer. Ann Rheum Dis, 54: 404-407.

33. Scanzello CR, Goldring SR (2012) The role of synovitis in osteoarthritis pathogenesis. Bone, 51: 249-257.

34. Schumacher HR Jr (1975) Ultrastructure of the synovial membrane. Ann Clin Lab Sci, 5: 489-498.

35. Scott DL, Wolfe F, Huizinga TWJ (2010) Rheumatoid arthritis. 1930. Lancet, 376: 1094-1108.

36. Sigurdson LA (1930) The structure and function of articular synovial membranes. J Bone Joint Surg Am, 12: 603-639.

37. Stevens CR, Blake DR, Merry P, Revell PA, Levick JR (1991) A comparative study by morphometry of the microvasculature in normal and rheumatoid synovium. Arthritis Rheum, 34: 1508-1513.

38. Suter ER, Majno G (1964) Ultrastructure of the joint capsule in the rat: presence of two kinds of capillaries. Nature, 202: 920-921.

39. Takeshita M, Nakamura J, Ohtori S, Inoue1 G, Orita S, Miyagi M, Isshikawa T, Takahashi K (2012) Sensory innervation and inflammatory cytokines in hypertrophic synovia associated with pain transmission in osteoarthritis of the hip: a case-control study. Rheumatology, 51: 1790-1795.

40. FCAT (Federative Committee on Anatomical Terminology) (1998) Terminologia Anatomica, International Anatomical Terminology, Thieme Stuttgart, New York.

41. Wilkinson LS, Edwards JCW (1989) Microvascular distribution in normal human synovium. J Anatomy, 167: 129-136.

42. Wilkinson LS, Pitsillides AA, Worrall JG, Edwards JCW (1992) Light microscopic characterization of the fibroblast-like synovial intimal cell (synoviocyte). Arthritis Rheum, 35: 1179-1184.

43. Zimny ML (1988) Mechanoreceptors in articular tissues. Am J Anat, 181: 16-32. 